\title{
Creating Joyful Learning within a Democratic Classroom
}

\begin{abstract}
Peter G. Waterworth
Deakin University, Australia

pewaterworth@yahoo.com.au
\end{abstract}

Received: May $09^{\text {th }}, 2020$

Revised: August $05^{\text {th }}, 2020$

Accepted: August $06^{\text {th }}, 2020$

\begin{abstract}
Learning is enhanced when it occurs within a positive environment where the learners feel a sense of passion and excitement about what they are learning. A joyful learning experience creates new neural pathways in the brain and enhances the acceptance of content. Learners learn more quickly and more deeply when their emotions are touched and the learning experience is accompanied by the positive feelings and reactions of their teacher and other fellow learners. This paper considers the factors and classroom processes that lead to positive learning sentiment and explores the way a teacher can create a suitable collaborative and democratic learning space.
\end{abstract}

Keywords: democratic classroom; joyful learning; play theory.

\section{UNDERSTANDING JOYFUL}

\section{LEARNING}

'Joy' is an attitude of constant inner satisfaction and comfort and is different from the fleeting and illusory experience of 'happiness'. Joy may be defined as a feeling or state of mind which is sustained by a sense of peace, passion or enthusiasm. Joyful learning is a series of pleasant and enjoyable learning experiences in which the teacher as well as the learners participate in active, personally fulfilling and successful learning episodes. Joyful learning maximises the personalities, the emotions and the senses of the learners in order to build more positive and long lasting learning outcomes.

There are a number of enemies of joy in learning. Classrooms are sometimes theatres of discomfort, challenge, uncertainty and incompleteness, depending upon the capabilities and intentions of their teachers. In attempting to motivate and stir learners, teachers often create more than questions or challenges but sometimes discomfort and disorganisation because they recognise the importance of the quest for knowledge, resolution of problems or the banishment of uncertainty in stimulating learning. There is no question that some learners respond very well to a certain level of discomfort and discombobulation. They relish the challenges and hurdles to personal achievement. These learners display a certain degree of confidence and self-assuredness. However, not all learners can boast such a level of 
maturity in their learning psyches. Most learners require an atmosphere of nurture and care to enable them to learn effectively. That is why a joyful classroom needs to be created and sustained.

The joyful classroom, while not being devoid of challenge and uncertainty, is set up to minimise stress and anxiety (Pawlak et al, 2003). It attempts to settle and resolve uncertainty and confusion in the students. It provides a mode of operation which seeks out and addresses instances of intolerance, intimidation and inflexibility (Willis, 2007) while at the same time eliminates meaningless repetition and boredom (ibid.). Joyful teachers are relaxed, personable and reassuring. They are interested primarily in creating an intellectual, social and emotional learning environment where learners will feel safe and confident yet willing to trust themselves to receive and face the challenges to their level of achievement and growth. Joyful teachers are reasonable, open and accepting of their learners' eccentricities, foibles and inconsistencies. They recognise that learning is spasmodic, halting and infinitely individual and that learning progress is incremental - sometimes slow and sometimes rapid. Joyful teachers are ordered and confident. They are tolerant and flexible in style but well versed and well-studied in their individual approach to teaching. But above all, joyful teachers are oftentimes surprising and constantly creative. They can transform the mundane into the personal and exciting and maintain the momentum of surprise in their students with élan and, thus, pique the creative energies of their students.

\section{JOYFUL LEARNING AND PLAY THEORY}

Although a number of writers have focussed passingly on the qualities of joyful learning, theirs is only a nascent theory of the approach in the literature. Play theory is a related or complementary concept although there are major theoretical differences between joyful learning and play theory. In the tradition of Loche and Rousseau, play theory is based on the use of play episodes or moments to achieve particular learning outcomes. Play or games are inserted deliberately into more extensive learning sequences to accelerate learning, typify concepts and develop fundamental skills or concepts. Play constitutes (sometimes informal) discrete activities (Huizinga, 1950, Rodriguez, 2006). Although play may be used most effectively within learning settings for all age groups, its main contribution to learning success is focussed on early childhood - especially exploratory play. Play, which often involves fun, provides a welcome relief from otherwise passive, dull and mundane learning. It may involve pretence, role play or rules which can be applied with great stringency or leniency - depending on the desired learning outcomes. Play can also involve the use of imagination, logic and meaning and can become quite symbolic (Dietze \& Kashin, 2011). On the other hand, joyful 
learning is far less episodic and more of a continuous state of being or an array of attitudes. Joyful learning can be practised equally well in school or adult learning settings. Its major distinguishing characteristic is that it involves playfulness or quirkiness (Sutton-Smith, 1997).

\section{OUTCOMES OF JOYFUL LEARNING}

Playfulness in learning is thought to reshape the structure of the brain (Thanos et al, 1999) by strengthening alternative neural pathways (Kohn 2004, Lester \& Russell, 2008). The element of joyfulness in learning is said to lead to superior socialisation in learners (Piaget, 1962, Vygotsky, 1962). Bodrora \& Leong (2005) argued that it led to superior academic outcomes and developed greater empathy in learners. If it occurs early enough in children's education, it is said to establish better patterns of learning in later schooling (Coolahan et al, 2000). It leads to better learning in terms of student motivation, persistence and peer interaction (Heywood, 2005, Shipley, 2008, Seligman, 2002, 2011) and increases concentration, curiosity and openness (SACSA, 2009). Joyful learning is thought to increase memory storage (Andreassen et al, 1999) and increase active learning (Dewey, 1938, Singh, 2014).

\section{UNDERSTANDING JOYFUL LEARNING}

This template is aimed at helping authors to prepare their manuscript for the Journal of Teaching and Learning in
Elementary Education. To use this template, the authors just delete the unwanted text and begin to type. The manuscript is written in good English. The authors can write either in British English or American English, but not both.

Body texts are written using tahoma 12 with 1 space. The manuscript should normally consist of the following parts: introduction, context and literature review, methods, results, discussion and conclusion. If necessary, the authors can add sub section.

\section{CREATING JOYFUL LEARNING}

A sterile approach to teaching will involve an over dependence upon textbooks accompanied by periods of drill and practice. While this method may eventually achieve results in terms of student learning outcomes, it does so at the expense of imagination, inventiveness and humour. The enemies of joyful learning are anxiety, stress, confusion, intolerance, intimidation and inflexibility. Teachers can do a great deal to enhance the joyful aspects of their teaching personae in both their attitudes to their own teaching and in the strategies they are willing to employ in the classroom.

\section{a. The joyful teacher}

Teachers have a vast array of options available to them in the way they present themselves to their students. They have a large repertoire of skills in their physical and emotional selves which they should use to provide variety and 
excitement to the learning experience of their students. A teacher's voice can provide variation in speed, volume, pitch, tone, emphasis and expression. Teachers rarely use all the voice resources they have available. A droning monotone voice which is used without emotion or expression will teach the students not to listen. Teachers should use their voices to provide surprise and drama.

Teachers also may provide variation in the position they occupy in the classroom while they are teaching. Their physical presence may be used to provide reassurance, dramatic change and challenge or discipline and so on, which will keep the students' levels of attention at a constantly superior level. For example, moving towards a particular student may be used to help discipline a child, to monitor a student's behaviour or to reassure a student of the teacher's continuing interest in that student's progress. Moving away from a student may be used to provide the opportunity for a teacher to encourage greater independence in that student or to encourage that student to raise their voice to a more audible level in answer to a question.

The teacher's decision to develop a more democratic classroom may also provide a big impetus to students in their willingness to express opinions freely and uncritically. Where a teacher is a strong authoritarian figure, students may be reluctant to provide more complex or sensitive responses or to reveal more personally challenging sides to themselves. It is important for a teacher to create a classroom atmosphere where students will feel relaxed and accepted, where all opinions will be able to be expressed without fear of criticism, where students can form their ideas or change their opinions as the express themselves. An atmosphere where all ideas are acceptable will generate better thought and clearer expression in the students. Such an atmosphere would also provide students with the need to develop logical responses, to provide evidence for their opinion and to justify their points of view.

\section{b. Joyful learners}

Teachers need to know the needs and interests of their students before they commence to plan learning activities for them. Learners have a variety of needs, are usually working at a variety of different ability levels, have preferred learning styles and respond differently to different teaching approaches. Teachers need to be aware of the differences between their students in order for them to meet those needs in the learning activities they provide. A joyful classroom draws upon the five senses of learners at a maximal level. Activities need to be devised that appeal to all senses because we know that if we increase the avenues of input into the brain that the message of the learning activity will be reinforced a number of times over.

Joyful learners revel in the opportunity to collaborate with one another. Collaborative or cooperative learning has been shown to enhance the effectiveness of learning episodes 
(Waterworth \& Duangpaeng, 2004). It also provides a different understanding of the learning process to the students. Students who are aware of their own learning strengths and weaknesses will find the process of cooperative learning enriching as they make use of the talents, skills and proclivities of other learners with whom the collaborate. Joyful learning focusses upon positive outcomes and relishes positive talk (Seligman, 2002, 2011).

Learning achievement is readily celebrated in a joyful classroom. Learning success can be celebrated in many ways some of which focus upon the success of the student themselves and sometimes of the task or product of the achievement. Where learners have their work marked by some kind of recognition, they become more appreciative of their developing skills as well as more motivated to develop their skills further.

\section{c. The joyful classroom}

Teachers have the scope to alter and envigorate the learning environment itself. The physical location of learning and physical arrangement of the learning space can be altered to provide greater levels of interest in students, greater appreciation of the adaptability of the learning process and more frequent elements of surprise. An unchanging learning environment, on the other hand, creates boredom and demotivates learners. The learning environment is not merely a place in which learning occurs. It provides a backdrop for learning and is integral to the learning experience itself. $A$ sterile and unchanging environment does not serve the purposes of the joyful teacher. A classroom should provide the basics of a necessary comfortable learning context but should also be a place which is controlled to provide variety, different levels of visual and aural stimulation and different types of interaction patterns between the teacher and students. A joyful classroom provides a variety of types of learning activities which give opportunities for students to interact with the teacher, one another and the learning materials (Australian Government, 2019). Joyful teachers take full advantage of multimedia learning opportunities because they realise that they can drastically enhance the learning experience of the students by so doing (Waterworth, Segrave \& Warren, 2001, Willis, 2007).

\section{OBJECTIONS TO JOYFUL LEARNING}

It may be claimed that joyful teaching is simply good teaching and that most teachers would be aware of the advantages of enthusiastic, committed teaching. All good teacher-preparation courses provide neophyte teachers with the essential of student motivation. Yet there seems to be a need to constantly remind teachers of the necessity to inject fun and surprise into teaching and to demonstrate how that should be done. Teachers need to be very resourceful and skilled to cope with the unexpected in the classroom and perhaps they need 
training in these approaches in order to refresh their skills.

Some education systems suffer the burden of systems of testing and examination. Compulsory governmentadministered examinations at various stages in the school system can have a stultifying impact upon teaching. Teachers become extremely aware of the implied evaluation of their own teaching that government examinations convey. They tend to 'teach to the examination' rather than teach the curriculum and this tends to encourage them to revert to 'drill and practice' teaching strategies. However, this is not a sufficient argument to eliminate joyful teaching. Teachers who are concerned that their students demonstrate sufficient progress in the government examinations can still employ the strategies of joyful teaching discussed above. In fact, the employment of such strategies, in all likelihood, would enhance student results in government examinations.

\section{CONCLUSION}

Joyful teachers provide an education in which their students can thrive academically, socially and emotionally. Their students gain from the inventiveness and unpredictability of the classroom with imagination and balance. The students gain a sense of confidence in themselves and in their peers and learn how to collaborate with and support one another.

In order to create a joy-filled classroom, joyful teachers need to develop their teaching personae in a number of ways. They need to create a desirable physical learning space that is sufficiently adaptable to permit the students to employ a number of learning approaches using a variety of learning media. They need to create a desirable social and emotional environment that is free of stress and anxiety and that will allow the students to develop wellrounded academic and creative approaches to their own learning and that will enable them to use a number of critical thinking skills without fear of criticism and embarrassment.

Joyful teachers feel free enough to express their own teaching personalities and to develop a flexible and responsive teaching style with which they can adequately engage each one of their students according to the students' learning proclivities. Joyful teachers allow themselves to be quirky, inventive and unpredictable. Their students are always ready to be surprised and challenged. Their students maintain a high level of self-motivation. Joyful teachers are at home with their own inventiveness and flexibility and feel confident and controlled. It could be suggested that joyful teachers exhibit an abundance of personal joy.

\section{REFERENCES}

Andreasen, N. C., O'Leary, D. S., Paradiso, S., Cizaldo, T., Arndt, S., Watkins, G. L., Ponto, L. L. \& Hichwa, R. D. (1999). The cerebellum plays a role in conscious episodic memory retrieval. Human Brain Mapping, 8(4), 226-234. 
Australian Government. (2019). Belonging, Being and Becoming: The Early Years Learning Framework for Australia. Department of Education, Canberra. (EYLFA) Originally published in 2009. Retrieved on $9 / 5 / 2020$ from https://docs.education.gov.au/node /2632

Bodrova, E. \& Leong, D. J. (2005). Uniquely preschool: What research tells us about the ways young children learn. Educational Leadership, 63(1), 44-47.

Coolahan, K.C., Fantuzzo, J., Mendez, J. \& McDermott, P. (2000). Preschool peer interactions and readiness to learn: Relationships between classroom peer play and learning behaviors and conduct. Journal of Educational Psychology, 92, 458465. Retrieved on $9 / 5 / 2020$ from http://www.imaginationplayground. com/images/content/2/9/2992/Pres chool-Peer-Interactions-andReadiness-To-Learn.pdf

Dewey, J. (1938). Democracy and Education. Simon and Schuster, New York.

Dietze, B. \& Kashin, D. (2011). Playing and Learning in Early Childhood Education. Pearson Education Canada, Toronto.

Department of Education, Employment and Workplace Relations (DEEWR). (2009). Belonging, being \& becoming: The Early Years Learning Framework for Australia (EYLFA). Canberra, DEEWR.
Heywood, P. (2005). Learning joyfully: an emotional and transformative experience. Melbourne Studies in Education 46(1), 33-44.

Huizinga, J. (1950). Homo Ludens, Roy Publishers, New York.

Kohn, A. (2004). Feel-bad education. Education Week, 24(3), 44-45.

Lester, S. \& Russell, S. (2008). Play for a change. Play policy and practice: A review of contemporary perspectives. Play England. Retrieved 9/5/2020 from http://www.worldleisure. org/pdfs/Copy\%20of\%20book_rev_ play_for_change.pdf

Pawlak, R., Magarinos, A. M., Melchor, J., McEwen, B. \& Strickland, S. (2003). Tissue plasminogen activator in the amygdala is critical for stressinduced anxiety-like behaviour. Nature Neuroscience, 6(2), 168174.

Piaget, J., (1962), Play, dreams and imitation in childhood, W. W. Norton \& Company, New York.

Rodriguez, H. (2006). The playful and the serious: An approximation to Huizinga's Homo Ludens. The International Journal of Computer Game Research, 6(1). Retrieved on 9/5/2020 from http://gamestudies.org/0601/article s/rodriges

Seligman, M. E. P. (2002). Authentic happiness: Using the new positive psychology to realize your potential for lasting fulfillment. Free Press, New York. 
Seligman, M. E. P. (2011). Flourish: A new understanding of happiness and well-being - and how to achieve them. Nicholas Brealey Publishing, London.

Shipley, D. (2008). Empowering children. Play based curriculum for lifelong learning. (Fourth edn). Nelson Education, Toronto.

Sutton-Smith, B. (1997). The Ambiguity of Play, Harvard University Press, Cambridge, MA.

Singh, S. (2014). Creating a joyful learning environment at primary level. Shaikshik Parisamvad (An International Journal of Education) 4(1), 10-14.

Thanos, P. K., Katana, J. M., Ashby, C. R., Michaeldes, M., Gardner, E. L., Heidbreder, C. A. (1999). The selective dopamine D3 receptor antagonist SB-277011-A attenuates ethanol consumption in ethanol preferring ( $P$ ) and non-preferring (NP) rats. Pharmacology, Biochemistry and Behavior, 81(1), 190-197.

Vygotsky, L. S., (1962), Thought and Language, Wiley, New York.

Waterworth, P.G., Segrave, S. \& Warren, C. (2001). 'New pedagogies: using constructivist insights in developing online studies in education'. In Lertchalolarn, C. et al (Eds), Reforming Teacher Education for the New Millennium: Searching for New Dimensions. Proceedings of the International Conference, Chulalongkorn University in association with SEAMEO RIHED, Bangkok, July 2000.

Waterworth, Peter and Duangpaeng, Amparn (2004) 'Contexts in cooperative learning: using cooperative learning strategies in teacher education in Australia and Thailand'. Paper presented at the International Association for the Study of Cooperation in Education National Institute of Education Conference, Singapore, June.

Willis, J. (2007). The Neuroscience of Joyful Education. Engaging the Whole Child, 64, summer. Retrieved on $9 / 5 / 2020$ from http://www.ascd.org/publications/e ducationalleadership/summer07/vol64/num09 LThe-Neuroscience-of-JoyfulEducation.aspx 